\title{
Associated Features with Non-Sentinel Lymph Node Involvement in Early Stage Breast Cancer Patients who Have Positive Macrometastatic Sentinel Lymph Node
}

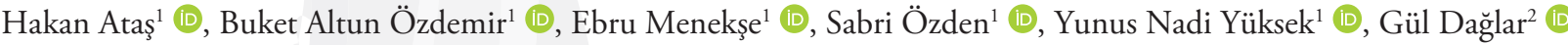 \\ ${ }^{1}$ Clinic of Breast and Endocrine Surgery, Ankara City Hospital, Ankara, Turkey \\ ${ }^{2}$ Clinic of Breast and Endocrine Surgery, Ankara Numune Research and Training Hospital, Ankara, Turkey
}

\begin{abstract}
Objective: The main goal of this study is to determine the clinico-pathological factors that correlate non-sentinel lymph nodes (LNs) involvement in clinically node negative breast cancer (BC) patients with positive macrometastatic sentinel lymph node (SLN) in order to derive future evidence to define a subgroup where completion axillary lymph node dissection (cALND) might not be recommended.

Materials and Methods: Total 289 SLN biopsies were performed in clinically node negative BC patients between March 2014 and April 2017. Seventy patients who performed cALND due to positive macrometastatic SLN were retrospectively selected and classified into two groups, according to non-SLN involvement (NSLNI). Clinico-pathological features of patients were examined computerized and documentary archives.

Results: Extracapsular extension (ECE) of SLN, number of harvested SLNs, metastatic rate of SLNs, absence of ductal carcinoma in situ (DCIS) and presence of multilocalization were significantly associated with the likelihood of non-SLN involvement after univariate analysis $(\mathrm{p}<0,05)$. Absence of DCIS and presence of multilocalization were found to be significant after multivariate analysis.

Conclusion: Careful examination of clinico-pathological features can help to decide avoiding cALND if enough LNs are removed and the rate of SLN metastases is low, particularly in case DCIS accompanying invasive cancer in patients without multi localized tumour.

Keywords: Breast cancer, lymphatic metastasis, sentinel lymph node biopsy

Cite this articles as: Ataş H, Altun Özdemir B, Menekşe E, Özden S, Yüksek YN, Dağlar G. Associated Features with Non-Sentinel Lymph Node Involvement in Early Stage Breast Cancer Patients who Have Positive Macrometastatic Sentinel Lymph Node. Eur J Breast Health 2020; 16(3): 192-197.
\end{abstract}

\section{Introduction}

The axillary nodal status is the most important prognostic factor in predicting the clinical outcomes in breast cancer (BC) patients. In recent years, sentinel lymph node biopsy (SLNB) has replaced axillary lymph node dissection (ALND) for an accurate staging and also to determine the prognosis and necessity of adjuvant therapies in BC patients with clinically negative axillary lymph nodes $(1,2)$. SLNB is a minimally invasive technique and safe, as well as lower morbidity compared with axillary dissection $(2,3)$. It is reported that the complication rates were, especially lymphedema, respectively 19.9\% vs. 5.6\% following ALND than SLNB during long-term follow-up (4).

When the sentinel lymph nodes (SLNs) are negative, ALND can be omitted due to the remaining axillary nodes were found free of disease (2). But it is still controversial to perform completion axillary lymph node dissection (cALND) in patients with SLN metastases (5). After the publishing ACASOG Z0011 and AMAROS studies, the importance of the non SLN involvement is considered less important $(6,7)$. However, cALND remains important for patients who have undergone mastectomy and cannot receive radiotherapy. After the IBCSG 23-01 study, the contribution of axillary dissection for micrometastatic lymph nodes to disease-free survival has not been demonstrated and there is still no standardization for axillary treatment (8). However, in most of the studies, while SLN positivity was identified, micro or macrometastasis was not differentiated $(5,6,9)$. Therefore, knowing the specific factors affecting NSLNI in patients with macrometastasis in SLN may make a difference in approach to axilla. In terms of refraining from morbidity of ALND and also keeping in oncological safety, it is important to identify the related factors with additional nodal disease in BC with SLN macrometastasis. 
The main goal of this study is to determine the clinico-pathological factors that correlate non-sentinel lymph nodes involvement in clinically node negative BC patients with positive SLN in order to derive future evidence to define a subgroup where cALND might not be recommended.

\section{Materials and Methods}

The clinically early stage BC patients with the clinically axillary node negative, who underwent SLNB at Breast and Endocrine Surgery Unit of Ankara Numune Research and Training Hospital between March 2014 to April 2017, were reviewed as retrospectively from the our computerized and documentary archives. Informed consent was obtained from patients at the time of enrolment in the registry. Institutional ethical committee of Ankara Numune Research and Training Hospital approved the study (Number of ethics committee approval: E-17-1429).

Patients, who underwent to ALND due to positive SLN were taken into this study. The cases with receiving neoadjuvant chemotherapy, micrometastases in SLN, isolated tumour cells and more than 6 removed SLNs were excluded from the study. All patients carried out ultrasounds of both breast and axilla and the patients aged more than 40 years underwent to mammography (MMG) for the purpose of diagnosis and treatment planning. Patients were diagnosed as BC according to excisional \& stereotactic biopsy, tru-cut biopsy and fine needle aspiration biopsy (FNAB) from suspicious breast mass. All the SLNB procedures were conducted via the use of blue dye such as patent blue, isosulfan blue and methylene blue. After the induction of anaesthesia, the blue dye was injected into the subareolar and perilesional areas in $10 \mathrm{~mL}$ volume and performed a massage to stimulate lymphatic drainage, for 10-12 minutes. Identified all blue nodes were accepted as SLNs and harvested. Pathologic evaluation of SLNs was performed with frozen section analysis intraoperatively, included sectioning at 2-mm intervals and staining with haematoxylin and eosin (H\&E). If lymph nodes were negative with $\mathrm{H} \& \mathrm{E}$, immunohistochemistry using cytokeratin antibody was performed. The determination of macrometastatic cells $(>2 \mathrm{~mm}$ ) within this period was described as a 'positive SLN' and further ALND was performed. Micrometastasis (0.2-2 $\mathrm{mm}$ ), cell clusters and isolated tumour cells of $<2 \mathrm{~mm}$ diameter were not accepted as a 'positive SLN' and so no more ALND performed.

Patient characteristics including age, side, localization and multilocalization of the tumour, presence of microcalcification on MMG, tumour characteristics including histological type, histological grade via the modified Bloom and Richardson system, tumour size, presence of lymphovascular invasion (LVI) and perineural invasion (PNI)

\section{Key Points}

- $\quad$ cALND in breast cancer patients with positive SLN still remains important for patients who have undergone mastectomy and can not receive radiotherapy.

- In order to avoid overtreatment due to morbidity of ALND, it is crucial to identify the factors associated with NSLNI.

- However, the problem with the practical use of existing nomograms was that some parameters used, such as LVI or ECE of SLN, were not known during the operation.

- This study suggests that cALND is less necessary in breast cancer patients with positive SLN accompanied by DCIS but without multilocalization. and status of estrogen receptor (ER), progesterone receptor (PR), cerbB2, p53, Ki67 and presence of DCIS accompanying invasive cancer, number of harvested SLNs and non-SLNs, SLN metastatic rate and extracapsular extension (ECE) of SLNs were assessed as possible estimated factors of axillary lymph node involvement. Multilocalization was defined as tumours that showed either or both multicentricity and multifocality. SLN metastatic rate was defined as the ratio of positive SLNs to total harvested SLNs.

After the final examination of enrolled surgical data and histopathological results, these patients with cALND were classified in two groups [(Group 1: non-sentinel lymph node involvement-, NSLNI $(-)$ and Group 2: non-sentinel lymph node involvement, NSLNI (+).

\section{Statistical analysis}

The relationship between clinico-pathological variables and groups which was divided according to axillary lymph node involvement was initially evaluated using univariate analysis. Continuous data are presented as mean $\pm S D$ while differences between groups were analysed by means of ANOVA test. Categorical variables were analysed with $\chi 2$ tests. Logistic regression was used to significant dependent variables associated with NSLNI. According to the number of risk factors which was independent variables, NSLNI rates was calculated by $\chi 2$ tests. A p-value less than 0.05 was considered statistically significant. All statistical tests were performed using IBM Statistical Package for the Social Sciences (IBM SPSS Corp.; Armonk, NY, USA), version 18.0 , software.

\section{Results}

SLN biopsies were performed in 289 clinically early stage BC patients. cALND were performed in 85 patients with positive SLN. Of these, 76 had macrometastases $(26.3 \%), 8$ had micrometastases $(2.7 \%)$ and $1(0.3 \%)$ had isolated tumour cells. And six other patients with more than 6 SLN excluded from the study. The remaining 70 patients were classified in two groups according to the involvement of non-SLN. A total of 32 patients in group 1 and 38 patients in group 2 were analysed. The age range was $21-80$ years (mean: $51.4 \pm 12.8$ ). There was no significant difference between groups in terms of age. We placed the diagnosis of malignancy with a tru-cut biopsy in 43 (62\%) and with excisional \& stereotactic biopsy in 27 (38\%). SLND was applied to all patients with the use of blue dye. Three types of blue dyes were used. Patent blue in 53 (76\%), isosulfan blue in $9(13 \%)$ and methylene blue in $8(11 \%)$. Multilocalization was seen in $11(15.7 \%)$ of $70 \mathrm{pa}-$ tients and was found significantly associated with NSLNI ( $\mathrm{p}=0.046)$. Forty-nine (70\%) patients were underwent breast-conserving surgery that included lumpectomy and $21(30 \%)$ modified radical mastectomy. The mean pathological tumour size was $2.400 .98 \mathrm{~cm}$. A total of $29(41.42 \%)$ had a T1 tumor size while $41(58.57 \%)$ patients with T2 tumor. The histological types of tumors were invasive ductal carcinoma (IDC) in 53 (76\%), invasive lobular carcinoma (ILC) in $11(16 \%)$, mixed invasive ductal and invasive lobular carcinoma in $3(4 \%)$ and other in 3 (4\%). Presence of DCIS accompanying invasive cancer histologically detected in 29 (41.4\%), and absence of DCIS accompanying invasive cancer found statistically significant correlation with nodal involvement $(\mathrm{p}=0.021)$. Additional positive lymph nodes after ALND were identified in 38 of 70 (54.3\%) patients with positive SLNs. The number of harvested SLN was minimum 1 and maximum 6 (mean: 2.921.42). SLN metastatic rate was $49 \%$ and $71.8 \%$ in group 1 (NSLNI-) and group 2 (NSLNI+), respectively. ECE of SLNs was detected in $16(22.8 \%)$ and all patients with ECE of SLNs were in group 2. 
Clinicopathologic characteristics and results of the histopathological examination of the primary tumor and axillary lymph nodes are shown in Table 1 and Table 2.

ECE of SLNs $(\mathrm{p}<0.001)$, number of harvested SLNs ( $\mathrm{p}=0.015)$, metastatic rate of SLNs ( $\mathrm{p}=0.01$ ), absence of DCIS accompanying invasive cancer $(\mathrm{p}=0.021)$ and multilocalization $(\mathrm{p}=0.046)$ were significantly associated with NSLNI on univariate analysis $(\mathrm{p}<0.05)$. These factors which were found to be significantly associated with NSLNI underwent to multivariate analysis. Multivariate analysis of potential risk factors showed that absence of DCIS accompanying invasive cancer $(\mathrm{p}=0.024)$ and presence of multilocalization $(\mathrm{p}=0.046)$ were independently associated with NSLNI in the present study (Table 3). If none, 1 or 2 of the risk factors is present, the estimated risks of NSLNI are found as $29.2 \%, 63.4 \%$ and $100 \%$, respectively (Table 4).

\section{Discussion and Conclusion}

Many studies investigated the different factors to predict the non-sentinel lymph node metastases in patients with positive $\operatorname{SLN}(5,9)$. The present study revealed that ECE of SLNs, number of harvested SLNs, metastatic rate of SLNs, absence of DCIS and presence of multilocalization were significantly associated with the likelihood of NSLNI in $\mathrm{BC}$ patients on univariate analysis. Of these, only absence of DCIS accompanying invasive cancer and multilocalization were found to be independent factors that effect NSLNI. Presence of DCIS was negatively associated with NSLNI. This parameter has not been examined and reported as the independent predictor of NSLNI previously. But Ramjeesingh et al. (9) reported the negatively association of DCIS and SLN involvement and suggested that women with DCIS and small

Table 1. Patient characteristics associated with NSLNI

\begin{tabular}{|c|c|c|c|}
\hline Characteristics & $\begin{array}{c}\text { Group 1: } \\
\text { NSLNI (-) } \\
n=32 \\
(45.7 \%)\end{array}$ & $\begin{array}{c}\text { Group 2: } \\
\text { NSLNI (+) } \\
n=38 \\
(54.3 \%)\end{array}$ & $\mathbf{p}$ \\
\hline Age (mean $\pm S D)$ & $48.4 \pm 11$ & $54.0 \pm 13.9$ & 0.07 \\
\hline \multicolumn{4}{|l|}{ Tumor localization \%, (n) } \\
\hline Right & $50 \%(16)$ & $31.5 \%(12)$ & \\
\hline Left & $50 \%(16)$ & $68.5 \%(26)$ & 0.117 \\
\hline \multicolumn{4}{|l|}{ Multilocalization \%, (n) } \\
\hline No & $93.7 \%(30)$ & $76.3 \%(29)$ & \\
\hline Yes & $6.3 \%(2)$ & $23.7 \%(9)$ & 0.046 \\
\hline \multicolumn{4}{|l|}{ Microcalcification \%, (n) } \\
\hline No & $65.6 \%(21)$ & $68.4 \%(26)$ & \\
\hline Yes & $34.4 \%(11)$ & $31.6 \%(12)$ & 0.804 \\
\hline $\begin{array}{l}\text { Number of harvested } \\
\text { SLNs (mean } \pm \text { SD) }\end{array}$ & $3.37 \pm 1.58$ & $2.55 \pm 1.17$ & 0.015 \\
\hline $\begin{array}{l}\text { Number of harvested } \\
\text { axillary nodes (mean } \pm S D \text { ) }\end{array}$ & $19.31 \pm 10.83$ & $19.21 \pm 5.89$ & 0.960 \\
\hline $\begin{array}{l}\text { Number of total positive } \\
\text { lymph node (mean } \pm S D \text { ) }\end{array}$ & $1.33 \pm 0.54$ & $8.28 \pm 8.55$ & $<0.01$ \\
\hline
\end{tabular}

Table 2. Pathologic characteristics breast cancer patients

\begin{tabular}{|c|c|c|c|}
\hline Characteristics & $\begin{array}{c}\text { Group 1: } \\
\text { NSLNI (-) } \\
n=32 \\
(45.7 \%)\end{array}$ & $\begin{array}{c}\text { Group 2: } \\
\text { NSLNI (+) } \\
n=38 \\
(54.3 \%)\end{array}$ & $\mathbf{P}$ \\
\hline $\begin{array}{l}\text { Tumour size } \\
(\mathrm{cm})(\text { mean } \pm S D)\end{array}$ & $2.32 \pm 0.75$ & $2.46 \pm 1.15$ & 0.549 \\
\hline \multicolumn{4}{|l|}{ DCIS \%, (n) } \\
\hline Absent & $43.7 \%(14)$ & $71 \%(27)$ & \\
\hline Present & $56.3 \%(18)$ & $29 \%(11)$ & 0.021 \\
\hline \multicolumn{4}{|l|}{ pT \%, (n) } \\
\hline $\mathrm{T} 1$ & $43.7 \%(14)$ & $39.5 \%(15)$ & \\
\hline $\mathrm{T} 2$ & $56.3 \%(18)$ & $60.5 \%(23)$ & 0.717 \\
\hline \multicolumn{4}{|l|}{$\mathrm{pN} \%$, (n) } \\
\hline N1 & $100 \%(32)$ & $34.2 \%(13)$ & \\
\hline N2 & $0 \%(0)$ & $63.1 \%(24)$ & \\
\hline N3 & $0 \%(0)$ & $2.7 \%(1)$ & $<0.001$ \\
\hline \multicolumn{4}{|l|}{ HG \%, (n) } \\
\hline HG 1 & $28.1 \%(9)$ & $18.4 \%(7)$ & \\
\hline HG 2 & $40.6 \%(13)$ & $50 \%(19)$ & \\
\hline HG 3 & $31.3 \%(10)$ & $31.6 \%(12)$ & 0.591 \\
\hline \multicolumn{4}{|l|}{ ER \%, (n) } \\
\hline Negative & $34.4 \%(11)$ & $26.3 \%(10)$ & \\
\hline Positive & $65.6 \%(21)$ & $73.7 \%(28)$ & 0.464 \\
\hline \multicolumn{4}{|l|}{ PR \%, (n) } \\
\hline Negative & $31.3 \%(10)$ & $31.6 \%(12)$ & \\
\hline Positive & $68.7 \%(22)$ & $68.4 \%(26)$ & 0.591 \\
\hline \multicolumn{4}{|l|}{ Cerb-B2 \%, (n) } \\
\hline Score 1 & $78.1 \%(25)$ & $71 \%(27)$ & \\
\hline Score 2 & $6.3 \%(2)$ & $10.6 \%(4)$ & \\
\hline Score 3 & $15.6 \%(5)$ & $18.4 \%(7)$ & 0.753 \\
\hline \multicolumn{4}{|l|}{ Ki $67 \%$, (n) } \\
\hline$\leq \% 15$ & $31.3 \%(10)$ & $15.7 \%(6)$ & \\
\hline$>\% 15$ & $25 \%(8)$ & $31.6 \%(12)$ & \\
\hline Unknown & $43.7 \%(14)$ & $52.7 \%(20)$ & 0,180 \\
\hline \multicolumn{4}{|l|}{ LVI \%, (n) } \\
\hline No & $56.3 \%(18)$ & $34.2 \%(13)$ & \\
\hline Yes & $43.7 \%(14)$ & $65.8 \%(25)$ & 0,064 \\
\hline \multicolumn{4}{|l|}{ PNI \%, (n) } \\
\hline No & $87.5 \%(28)$ & $71 \%(27)$ & \\
\hline Yes & $12.5 \%(4)$ & $29 \%(11)$ & 0,095 \\
\hline SLN metastatic rate (\%)* & 49.0 & 71.8 & 0.01 \\
\hline \multicolumn{4}{|l|}{ ECE of SLNs \%, (n) } \\
\hline No & $100 \%(32)$ & $57.9 \%(22)$ & \\
\hline Yes & $0 \%(0)$ & $42.1 \%(16)$ & $<0.001$ \\
\hline \multicolumn{4}{|c|}{$\begin{array}{l}\text { *SLN metastatic rate =positive SLNs/ harvested SLNs. NSLNI: non-sentinel } \\
\text { lymph node involvement; DCIS: ductal carcinoma in situ; ER: estrogen } \\
\text { receptor; PR: progesterone receptor; Cerb-B2: epidermal growth factor } \\
\text { receptor 2; LVI: lymphovascular invasion; PNI: perineural invasion; SLN: } \\
\text { sentinel lymph node; ECE: extracapsular extension; HG: histologic grade. }\end{array}$} \\
\hline
\end{tabular}


Table 3. Multivariate analysis of clinical and pathological characteristics associated with NSLNI

\begin{tabular}{|c|c|c|c|}
\hline Characteristic & Odds Ratio & $95 \% \mathrm{Cl}$ & $\mathbf{p}$ \\
\hline Presence of multilocalization & 8.285 & $0.02-0.92$ & 0.046 \\
\hline $\begin{array}{l}\text { Absence of DCIS accompanying } \\
\text { invasive cancer }\end{array}$ & 5.464 & $0.042-0.802$ & 0.024 \\
\hline Number of harvested SLNs & - & - & 0.163 \\
\hline SLN metastatic rate (\%) & - & - & 0.781 \\
\hline ECE of SLNs & - & - & 0.998 \\
\hline
\end{tabular}

NSLNI: non-sentinel lymph node involvement; Cl: confidence interval; DCIS: ductal carcinoma situ; SLN: sentinel lymph node; ECE: extracapsular extension.

\section{Table 4. Correlation of risk factors (Presence of multilocalization and DCIS accompanying invasive cancer)}

\begin{tabular}{|c|c|c|c|}
\hline $\begin{array}{l}\text { Number } \\
\text { of risk } \\
\text { factors }\end{array}$ & $\begin{array}{c}\text { Group 1: } \\
\text { NSLNI (-) } \\
\text { (n=32, } \\
45.7 \%)\end{array}$ & $\begin{array}{c}\text { Group 2: } \\
\text { NSLNI (+) } \\
(n=38 \\
54.3 \%)\end{array}$ & $\mathbf{p}$ \\
\hline 0 & $53.1 \%(17)$ & $18.4 \%(7)$ & 0.03 \\
\hline 1 & $46.9 \%(15)$ & $68.4 \%(26)$ & \\
\hline 2 & $0 \%(0)$ & $13.2 \%(5)$ & \\
\hline
\end{tabular}

low-grade tumours may not require assessment of SLNs, intraoperatively. Another parameter that we examined was multilocalization. Multifocal/multicentric tumours are described as a presence of two or more discrete tumours in the same breast (in the same quadrant for multifocal tumours and different quadrants for multicentric tumours). As emphasized in the literature, multifocal/multicentric BCs have a higher rates of lymph node metastasis. Andea et al. (10) reported the relation between multifocality and axillary metastases. Similarly, we found multilocalization of the primary tumour as a predictor of NSL$\mathrm{NI}$ in the present study. Moreover $81.8 \%$ of patients with multilocality had additional axillary metastases. Although the number of patients in this study is low, if all independent predictive factors were present, $100 \%$ of cases with positive SLNs were found to have NSLNI+.

The relationship between tumour size and possibility of NSLNI has been reported in many studies. Ozmen et al. (11) found that tumour size larger than $2 \mathrm{~cm}$ was associated with higher risk of NSLNI. Also, Joseph et al. (12) demonstrated that primer tumour size was a predictor of NSLNI. The rates of metastatic non-SLNs were $0 \%, 12 \%$ and $47 \%$ for patients with T1a, T1b and T1c, respectively. But in the present study we could not find it as a statistically significant feature in both univariate and multivariate analysis. Similarly, Boler et al. (13), Abdessalam et al. (14) and Rahusen et al. (15) could not find an association between tumour size and NSLNI. High histological grade is another parameter that associated with an increased risk of NSLN (16, 17). But we could not find histological grade as a statistically significant predictive factor like previously demonstrated $(18,19)$.
Although many studies $(14,17)$ have reported similar results that LVI was enough to predict NSLNI, the univariate analyses revealed no significant differences between LVI and NSLNI in the current study.

Status of steroid receptors (particularly PR, not ER), Her-2 neu and Ki 67 mentioned as an independent predictive factors of axillary lymph node metastases previously (20). Also, we could not demonstrate any association between these parameters and NSLNI in our study.

Hwang et al. (18) reported that an increasing number of harvested SLNs is another parameter that associated with the likelihood of having additional lymph node metastases. Our study validated this association also. Number of positive SLNs and SLN metastatic rate (positive SLNs/ harvested SLNs) are the other demonstrated parameters that associated with NSLNI by two different studies $(21,22)$. The present study did not examine the number of positive SLNs as a predictor of NSLNI. But the univariate analyses revealed significant differences between two groups in terms of metastatic rate of SLN. Additionally, the significance rates were higher in patients with three or more harvested SLNs. However, the significance was lost in the multivariate analysis.

Size of the metastases in SLNs were usually defined as macrometastases $(\leq 2 \mathrm{~mm})$, micrometastases $(\leq 2 \mathrm{~mm})$ and isolated tumor cells $(>2 \mathrm{~mm})$ with the rates of non-SLN positivity, $48 \%, 23 \%$ and $12.5 \%$, respectively (23). Due to the low metastatic rates, in our clinic we do not perform cALND in patients with micrometastases and isolated tumour cells in SLNs already. Therefore, these subjects were not studied in the present study. Besides size of the metastases, ECE of SLNs concerns us about the tumour cells in transit to other sites. ECE in SLN was demonstrated as a significant predictor of increased NSLNI for many times (24). In concordance with previous reports, in our study $100 \%$ of patients with ECE had NSLNI while $40.7 \%$ of patients without ECE were found to have additional axillary nodal metastases.

Based upon the most of clinicopathological features that mentioned above, many different nomograms have been developed, previously. In 2003, a nomogram by Van Zee et al. (22) from the Memorial Sloan Kettering Cancer Center (MSKCC) was published. This nomogram was based on eight parameters (type, size and grade of tumour, detection method of SLN, LVI, multifocality, ER status and SLN metastatic rate). Stanford model was reported in 2008, for predicting the NSLNI in SLN positive BC patients as another one, Cambridge model $(25,26)$. In fact, all of these nomograms were based on the synergistic interaction of these factors. But the problem in the practical use of nomograms was that some of the parameters used were not known during the operation such as LVI, ECE of SLN, ER status. Moreover, these nomograms based on the populations own features where they developed so they are in need to be validated in different patient populations. In different studies it was shown that Gur et al. (27) reported that the MSKCC nomogram, Cambridge Formula and Stanford nomogram were good discriminators for Turkish population, in their validation study. However, some other validation studies did not find nomograms reliable particularly for SLNs with micrometastatic involvement $(28,29)$.

The strengths of this study can be stated as follows. All the operations were applied by experienced surgeons of General Surgery Clinic, Breast and Endocrine Surgery Department. And pathological examinations were done by pathologists with the help of surgeons. Patients with neoadjuvant chemotherapy and more than 6 removed SLNs, who were thought to be able to influence the results of the statistical 
analysis were excluded from the study. cALND was performed to all patients with a positive SLN.

On the other hand, the current study reflects the typical features of BC patients. The most important limitations of this study are, insufficient number of patients, the retrospective nature and detection method of SLN. We used only blue dye as a signing method of SLN. But also emphasized in the literature, both radioisotope and blue dye can be used to identify the SLNs in ESBC patients with the rate of $99 \%$ (30). With the use of the combined technique, the number of sentinel lymph nodes removed could be increased, which could affect the results in different ways.

In conclusion, this retrospective study demonstrated absence of DCIS accompanying invasive cancer as an independent predictor of NSLNI that has not mentioned in literature previously. Also, presence of multilocalization was found another important predictive factor of the lymph node metastasis. Careful examination of clinicopathologic features can help to decide avoiding cALND if enough lymph nodes are removed and the rate of SLN metastases is low, particularly in patients with presence of DCIS accompanying invasive cancer but without multilocalization. Finally, this study cannot be used to predict the NSLNI in daily clinical practice but may provide insight into new studies. Because there is still an ongoing argument on the predictive factors of axillary LN involvement. Future studies are needed to reveal more accurate subgroups of patients that might be avoided of axillary overtreatment in BC patients with SLN positive.

Ethics Committee Approval: Ethics committee approval was received for this study from the ethics committee of Ankara Numune Training and Research Hospital (Number of ethics committee approval: E-17-1429).

Informed Consent: Informed consent was obtained from all individual participants included in the study.

Peer-review: Externally peer-reviewed.

Author Contributions: Concept - H.A., B.A.Ö., E.M.; Design - B.A.Ö., E.M., Y.N.Y.; Supervision - Y.N.Y., G.D.; Data Collection and/or Processing - H.A., B.A.Ö., S.Ö.; Analysis and/or Interpretation -E.M., S.Ö., Y.N.Y.; Literature Search - H.A., B.A.Ö., S.Ö.; Writing Manuscript - H.A., E.M.; Critical Review - E.M., Y.N.Y., G.D.

Conflict of Interest: The authors have no conflicts of interest to declare.

Financial Disclosure: The authors declared that this study has received no financial support.

\section{References}

1. Hennigs A, Köpke M, Feißt M, Riedel F, Rezai M, Nitz U, Moderow M, Golatta M, Sohn C, Schneeweiss A, Heil J. Which patients with sentinel node-positive breast cancer after breast conservation still receive completion axillary lymph node dissection in routine clinical practice? Breast Cancer Res Treat 2019; 173: 429-438. (PMID: 30315437) [Crossref]

2. Karahallı Ö, Acar T, Atahan MK, Acar N, Haciyanlı M, Kamer KE. Clinical and Pathological Factors Affecting the Sentinel Lymph Node Metastasis in Patients with Breast Cancer. Indian J Surg 2017; 79: 418-422. (PMID: 29089701) [Crossref]

3. Krag DN, Anderson SJ, Julian TB, Brown AM, Harlow SP, Costantino JP, Ashikaga T, Weaver DL, Mamounas EP, Jalovec LM, Frazier TG, Noyes RD, Robidoux A, Mc Scarth H, Wolmark N. Sentinel-lymph-node clinically node-negative patients with breast cancer: overall survival findings from the NSABP B-32 randomised phase 3 trial. Lancet Oncol 2010; 11: 927-933. (PMID: 20863759) [Crossref]

4. Janni W, Kühn T, Schwentner L, Kreienberg R, Fehm T, Wöckel A. Sentinel node biopsy and axillary dissection in breast cancer: the evidence and its limits. Dtsch Arztebl Int 2014; 111: 244-249. (PMID: 24766712)

5. Zendejas B, Hoskin TL, Degnim AC, Reynolds CA, Farley DR, Boughey JC. Predicting four or more metastatic axillary lymph nodes in patients with sentinel node-positive breast cancer: assessment of existent risk scores. Ann Surg Oncol 2010; 17: 2884-2891. (PMID: 20429038) [Crossref]

6. Giuliano AE, Ballman K, McCall L, Beitsch P, Whitworth PW, Blumencranz P, Leitch AM, Saha S, Morrow M, Hunt KK. Locoregional recurrence after sentinel lymph node dissection with or without axillary dissection in patients with sentinel lymph node metastases: long-term follow-up from the American College of Surgeons Oncology Group (Alliance) ACOSOG Z0011 randomized trial. Ann Surg 2016; 264: 413-420. (PMID: 27513155) [Crossref]

7. Donker M, van Tienhoven G, Straver ME, Meijnen P, van de Velde CJH, Mansel RE, Cataliotti L, Westenberg AH, Klinkenbijl JHG, Orzalesi L, Bouma WH, van der Mijle HCJ, Nieuwenhuijzen GAP, Veltkamp SC, Slaets L, Duez NJ, de Graaf PW, van Dalen T, Marinelli A, Rijna H, Snoj M, Bundred NJ, Merkus JWS, Belkacemi Y, Petignat P, Schinagl DAX, Coens C, Messina CGM, Bogaerts J, Rutgers EJT. Radiotherapy or surgery of the axilla after a positive sentinel node in breast cancer (EORTC 10981-22023 AMAROS): a randomised, multicentre, open-label, phase 3 non-inferiority trial. Lancet Oncol 2014; 15(12), 1303-1310. (PMID: 25439688)

8. Galimberti V, Cole BF, Zurrida S, Viale G, Luini A, Veronesi P, Baratella P, Chifu C, Sargenti M, Intra M, Gentilini O, Mastropasqua MG, Mazzarol G, Massarut S, Garbay JR, Zgajnar J, Galatius H, Recalcati A, Littlejohn D, Bamert M, Colleoni M, Price KN, Regan MM, Goldhirsch A, Coates AS, Gelber RD, Veronesi U; International Breast Cancer Study Group Trial 23-01 investigators. Axillary dissection versus no axillary dissection in patients with sentinel-node micrometastases (IBCSG 23-01): a phase 3 randomised controlled trial. Lancet Oncol 2013; 14: 297-305. (PMID: 23491275) [Crossref]

9. Ramjeesingh R, Quan ML, Gardner S, Holloway CM. Prediction of involvement of sentinel and nonsentinel lymph nodes in a Canadian population with breast cancer. Can J Surg 2009; 52: 23-30. (PMID: 19234648)

10. Andea AA, BouwmanD, Wallis T, Visscher DW. Correlation of tumor volume and surface area with lymph node status in patients with multifocal/multicentric breast carcinoma. Cancer 2004; 100: 20-27. (PMID: 14692020) [Crossref]

11. Ozmen V, Karanlik H, Cabioglu N, Igci A, Kecer M, Asoglu O, Tuzlali S, Mudun A. Factors predicting the sentinel and non-sentinel lymph node metastases in breast cancer. Breast Cancer Res Treat 2006; 95: 1-6. (PMID: 16322900) [Crossref]

12. Joseph KA, El-Tamer M, Komenaka I, Troxel A, Ditkoff BA, Schnabel F. Predictors of nonsentinel node metastasis in patients with breast cancer after sentinel node metastasis. Arch Surg 2004; 139: 648-651. (PMID: 15197092) [Crossref]

13. Boler DE, Uras C, Ince U, Cabioglu N. Factors predicting the non-sentinel lymph node involvement in breast cancer patients with sentinel lymph node metastases. Breast 2012; 21: 518-523. (PMID: 22410110) [Crossref]

14. Abdessalam SF, Zervos EE, Prasad M, Farrar WB, Yee LD, Walker MJ, Carson WB, Burak WE Jr. Predictors of positive axillary lymph nodes after sentinel lymph node biopsy in breast cancer. Am J Surg 2001; 182: 316-320. (PMID: 11720662) [Crossref]

15. Rahusen FD, Torrenga H, van Diest PJ, Pijpers R, van der Wall E, Licht J, Meijer S. Predictive factors for metastatic involvement of nonsentinel nodes in patients with breast cancer. Arch Surg 2001; 136: 1059-1063. (PMID: 11529831) [Crossref]

16. Bader AA, Tio J, Petru E, Bühner M, Pfahlberg A, Volkholz H, Tulusan AH. T1 breast cancer: identification of patients at low risk of axil- 
lary lymph node metastases. Breast Cancer Res Treat 2002; 76: 11-17. (PMID: 12408371) [Crossref]

17. Syed A, Eleti S, Kumar V, Ahmad A, Thomas H. Validation of Memorial Sloan Kettering Cancer Center nomogram to detect non-sentinel lymph node metastases in a United Kingdom cohort. Il G Chir 2018; 39: 12-19. (PMID: 29549676) [Crossref]

18. Hwang RF, Krishnamurthy S, Hunt KK, Mirza N, Ames FC, Feig B, Kuerer HM, Singletary SE, Babiera G, Meric F, Akins JS, Neely J, Ross MI. Clinicopathologic factors predicting involvement of nonsentinel axillary nodes in women with breast cancer. Ann Surg Oncol 2003; 10: 248254. (PMID: 12679309) [Crossref]

19. Cserni G, Gregori D, Merletti F, Sapino A, Mano MP, Ponti A, Sandrucci S, Baltás B, Bussolati G. Meta-analysis of non-sentinel node metastases associated with micrometastatic sentinel nodes in breast cancer. Br J Surg 2004; 91(10): 1245-1252. (PMID: 15376203) [Crossref]

20. Mustać E, Matušan-Ilijaš K, Marijić $B$, Smokvina M, Jonjić N. Predicting the likelihood of additional nodal metastases in breast carcinoma patients with positive sentinel node biopsy. Int J Surg Pathol 2010; 18: 36-41. (PMID: 19448065) [Crossref]

21. Wada N, Imoto S, Yamauchi C, Hasebe T, Ochiai A. Predictors of tumor involvement in remaining axillary lymph nodes of breast cancer patients with positive sentinel lymph node. Eur J Surg Oncol 2006; 32: 29-33. (PMID: 16269227) [Crossref]

22. Van Zee KJ, Manasseh DME, Bevilacqua JL, Boolbol SK, Fey JV, Tan LK, Borgen PI, Cody HS 3rd, Kattan MW. A nomogram for predicting the likelihood of additional nodal metastases in breast cancer patients with a positive sentinel node biopsy. Ann Surg Oncol 2003; 10: 11401151. (PMID: 14654469) [Crossref]

23. Singletary SE, Allred C, Ashley P, Bassett LW, Berry D, Bland KI, Borgen PI, Clark G, Edge SB, Hayes DF, Hughes LL, Hutter RV, Morrow M, Page DL, Recht A, Theriault RL, Thor A, Weaver DL, Wieand HS, Greene FL. Revision of the American Joint Committee on Cancer staging system for breast cancer. J Clin Oncol 2002; 20: 3628-3636. (PMID: 12202663) [Crossref]
24. Gooch J, King TA, Eaton A, Dengel L, Stempel M, Corben AD, Morrow $M$. The extent of extracapsular extension may influence the need for axillary lymph node dissection in patients with T1-T2 breast cancer. Ann Surg Oncol 2014; 21: 2897-2903. (PMID: 24777858) [Crossref]

25. Kohrt HE, Olshen RA, Bermas HR, Goodson WH, Wood DJ, Henry S, Rouse RV, Bailey L, Philben VJ, Dirbas FM, Dunn JJ, Johnson DL, Wapnir IL, Carlson RW, Stockdale FE, Hansen NM, Jeffrey SS; Bay Area SLN Study. New models and online calculator for predicting nonsentinel lymph node status in sentinel lymph node positive breast cancer patients. BMC Cancer 2008; 8: 66. (PMID: 18315887) [Crossref]

26. Pal A, Provenzano E, Duffy SW, Pinder SE, Purushotham AD. A model for predicting non-sentinel lymph node metastatic disease when the sentinel lymph node is positive. Br J Surg 2008; 95: 302-309. (PMID: 17876750) [Crossref]

27. Gur AS, Unal B, Ozbek U. Validation of breast cancer nomograms for predicting the non-sentinel lymph node metastases after a positive sentinel lymph node biopsy in a multi-center study. Eur J Surg Oncol 2010; 36: 30-35. (PMID: 19535217) [Crossref]

28. Alran S, De Rycke Y, Fourchotte V, Charitansky H, Laki F, Falcou MC, Benamor M, Freneaux P, Salmon RJ; Institut Curie Breast Cancer Study Group, Sigal-Zafrani B. Validation and limitations of use of a breast cancer nomogram predicting the likelihood of non-sentinel node involvement after positive sentinel node biopsy. Ann Surg Oncol 2007; 14: 2195-2201. (PMID: 17294071) [Crossref]

29. van la Parra RF, Ernst MF, Bevilacqua JL, Mol SJ, Van Zee KJ, Broekman JM, Bosscha K. Validation of a nomogram to predict the risk of nonsentinel lymph node metastases in breast cancer patients with a positive sentinel node biopsy: validation of the MSKCC breast nomogram. Ann Surg Oncol 2009; 16: 1128-1135. (PMID: 19252954) [Crossref]

30. Newman EA, Newman LA. Lymphatic mapping techniques and sentinel lymph node biopsy in breast cancer. Surg Clin North Am 2007; 87: 353 364. (PMID: 17498531) [Crossref] 